\title{
RELATIONSHIP BETWEEN WORK ABILITY IN NURSING AND MINOR PSYCHOLOGICAL DISORDERS
}

\author{
Tânia Solange Bosi de Souza Magnago ${ }^{1}$, Andrea Prochnow ${ }^{2}$, Janete de Souza Urbanetto ${ }^{3}$, Patrícia Bitencourt \\ Toscani Greco', Marlize Beltrame ${ }^{5}$, Emanuelli Mancio Ferreira da Luz ${ }^{6}$
}

${ }^{1}$ Ph.D. in Nursing. Adjunct Professor, Nursing Department and Graduate Program (PPGEnf) at Universidade Federal de Santa
Maria (UFSM). Santa Maria, Rio Grande do Sul, Brazil. E-mail: tmagnago@terra.com.br
${ }^{2}$ M.Sc. in Nursing. Santa Maria, Rio Grande do Sul, Brazil. E-mail: andrea.prochnow@yahoo.com.br
${ }^{3}$ Ph.D. in Health Sciences. Adjunct Professor, School of Nursing, Physiotherapy and Nutrition at Pontifícia Universidade Católica
do Rio Grande do Sul. Porto Alegre, Rio Grande do Sul, Brazil. E-mail: jurbanetto@pucrs.br
${ }^{4}$ M.Sc. in Nursing. Professor, Undergraduate Nursing Course, Universidade Regional Integrada do Alto Uruguai e das Missões -
campus Santiago. Santiago, Rio Grande do Sul, Brazil. E-mail: pbtoscani@hotmail.com
${ }^{5}$ Master's student in Nursing in PPGEnf/UFSM. Santa Maria, Rio Grande do Sul, Brazil. E-mail: m-beltrane@bol.com.br
${ }^{6}$ Master's student in Nursing in PPGEnf/UFSM. Santa Maria, Rio Grande do Sul, Brazil. E-mail: emanuelli_ferreira@hotmail.com

ABSTRACT: This study aimed to evaluate the association between minor psychological disorders and the reduction of work capacity of nursing professionals. Epidemiological study (cross-sectional) involving 498 (84.1\%) nursing professionals at a university hospital in the state of Rio Grande do Sul, Brazil. We used the Brazilian versions of the Work Ability Index and the Self-Reporting Questionnaire-20, with descriptive and multivariate analysis. The prevalence of minor psychological disorders and the reduction of work ability corresponded to $33.7 \%$ and $43.3 \%$, respectively. The analyses adjusted due to confounding factors showed that nursing professionals with suspected minor psychological disorders were twice as likely to have their work ability reduced when compared to those without suspected minor psychological disorders. It is concluded that there is a positive association between minor psychological disorders and reduced work ability among the investigated professionals. Measures are needed to minimize the psychological demands and empower the work ability.

DESCRIPTORS: Nursing. Work capacity evaluation. Occupational health. Occupational diseases. Mental disorders.

\section{RELAÇÃO ENTRE CAPACIDADE PARA O TRABALHO NA ENFERMAGEM E DISTÚRBIOS PSÍQUICOS MENORES}

RESUMO: Este estudo objetivou avaliar a associação entre distúrbios psíquicos menores e a redução da capacidade de trabalho em trabalhadores de enfermagem. Estudo epidemiológico transversal, envolvendo 498 (84,1\%) trabalhadores de enfermagem de um hospital universitário do Estado do Rio Grande do Sul, Brasil. Utilizaram-se versões brasileiras do Índice de Capacidade para o Trabalho e do Self-Reporting Questionnaire-20, com análise descritiva e multivariada. As prevalências de distúrbios psíquicos menores e da redução da capacidade para o trabalho foram de 33,7\% e 43,3\%, respectivamente. As análises ajustadas pelos fatores de confundimento evidenciaram que os trabalhadores de enfermagem com suspeição para distúrbios psíquicos menores apresentaram duas vezes mais chances de ter a capacidade para o trabalho reduzida quando comparados aos sem suspeição. Conclui-se que há associação positiva entre distúrbios psíquicos menores e redução da capacidade para o trabalho nos trabalhadores pesquisados. São necessárias medidas que minimizem as exigências mentais e que potencializem a capacidade para o trabalho.

DESCRITORES: Enfermagem. Avaliação da capacidade de trabalho. Saúde do trabalhador. Doenças profissionais. Transtornos mentais.

\section{RELACIÓN ENTRE LA CAPACIDAD DE TRABAJO EN ENFERMERÍA Y TRASTORNOS PSÍQUICOS MENORES}

RESUMEN: Estudio tuvo como objetivo evaluar la asociación entre trastornos psíquicos menores y la reducción de la capacidad de trabajo en los profesionales de enfermería. Estudio epidemiológico transversal con $498(84,1 \%)$ profesionales de un hospital universitario en el Estado de Rio Grande do Sul, Brasil. Fueron utilizadas versiones brasileñas del Índice de Capacidad de Trabajo y del Self-Reporting Questionnaire-20, con el análisis descriptivo y multivariado. La prevalencia de los trastornos psíquicos menores y la reducción de la capacidad de trabajo fueron 33,7 y y 43,3 \%, respectivamente. Los análisis mostraron que los profesionales con sospecha de trastornos psíquicos menores tuvieron dos veces más posibilidades de tener la capacidad de trabajo reducida comparados con los de sin sospecha de trastornos psíquicos menores. Se concluye que existe una asociación positiva entre trastornos psíquicos menores y reducción de la capacidad de trabajo en los profesionales investigados. Se necesitan medidas para disminuir las exigencias mentales y que potencialicen la capacidad para el trabajo.

DESCRIPTORES: Enfermería. Evaluación de capacidad de trabajo. Salud laboral. Enfermedades profesionales. Trastornos mentales. 


\section{INTRODUCTION}

Work ability can be described as the physical and mental capacity of the professional to perform tasks, taking into account work requirements. ${ }^{1} \mathrm{~A}$ Finnish study showed that the work ability is not satisfactory for the entire life. Some factors, such as working conditions, occupational environment and lifestyle can influence it. ${ }^{1}$

In the hospital context, workers are exposed to different workloads ${ }^{2}$ and occupational risk situations that can have physical and psychic ${ }^{3}$ repercussions, represented, for example, by reduction of work capacity ${ }^{1}$ and Minor Psychiatric Disorders (MPDs), ${ }^{4}$ respectively.

The MPDs indicate clinical cases of individuals with symptoms of anxiety, depression or somatization, which do not fulfill the criteria of mental illness according to the International Classification of Diseases (ICD-10). ${ }^{5}$

In nursing, the MPD reports gain increasing proportions as causes of illnesses ${ }^{4}$ and can influence work ability. Surveys on work ability in nursing professionals have been the subject of national ${ }^{6-8}$ and international studies, ${ }^{9}$ which shows the interest of researchers in identifying situations that may affect the health of these people in the labor context and may define action strategies in the quest for health promotion.

A research gap still remains, however, regarding the association between MPDs and reduction of work capacity. Advanced searches were performed in the Latin American and Caribbean Health Sciences (LILACS), in the virtual library Scientific Electronic Library Online (SCIELO) and in the Medical Literature Analysis and Retrieval System Online (MEDLINE) databases, during February 2014. The descriptor "work ability assessment" was used in association with "mental disorders" to identify minor psychiatric disorders, because there were no studies that evaluated these two issues simultaneously. It is highlighted that, in the State of Rio Grande do Sul, mental disorders are the second leading cause of notification of occupational disease. ${ }^{10}$

Based on these considerations, the guiding question of this study was: is there an association between MPD and work ability in nursing? Our hypothesis is that nursing workers with suspected MPD present a higher risk for the reduction of work capacity. In order to confirm or refute this hypothesis, the present study aims to determine the association between MPD and reduction of work capacity in nursing workers at a university hospital in the State of Rio Grande do Sul.

\section{METHOD}

Cross-sectional study, which used the research database entitled "Functional capacity of nursing workers with WMSD/RSI (WorkRelated Musculoskeletal Disorders/Repetitive Strain Injuries)", approved by the Institutional Review Board of the Universidade Federal de Santa Maria (CAAE: 0070.0.243.000-09), and linked the Research Group Work, Health, Education and Nursing at the Department of Nursing of the same University.

The place of study was the University Hospital of Santa Maria (UHSM), located in the MidWest of the state of Rio Grande do Sul, Brazil. Data collection occurred in 2009, by completing a questionnaire, during the study participants' work hours.

The study population consisted of 592 nursing workers. Of this total, $498(84.1 \%)$ participated in the study. Losses $(15.8 \%$; $=94)$ resulted from refusals to participate in the research.

The following inclusion criteria were established: being a nurse, medical technician or nursing assistant from the UHSM staff. And, as exclusion criteria: being a nursing worker with temporary contracts, being on leave or away from work, or on vacation during the collection period.

The exposure to Minor Psychiatric Disorders (independent variable) was assessed, using the version validated in Brazil ${ }^{11}$ of the Self-Reporting Questionnaire-20 (SRQ-20). This instrument contains 20 questions on symptoms and problems that have occurred in the last 30 days before the data collection. Table 1 shows the items in the SRQ-20 by group of symptoms. ${ }^{12}$ It is noteworthy that, in this variable, of the 498 participants, 68 (13.6\%) left one or more questions of the SRQ-20 blank. It was decided to exclude them, totaling 430 valid questionnaires for the analysis of this variable.

In the SRQ-20, the alternative scores were zero $(0)$ or one (1), wherein score 1 indicates that 
the symptom was present in the last month, and zero (0) that it was absent. ${ }^{11,13}$ For suspected MPD, seven positive responses for both men and women were considered as the cut-off point, based on previous research with nursing workers. ${ }^{14}$ The overall raw Cronbach's Alpha coefficient of the SRQ-20 was 0.84 .

The work ability (outcome) was assessed by using the version translated into Portuguese of the Work Ability Index (WAI). ${ }^{1}$ The WAI was prepared by the Finnish Institute of Occupational Health $(\mathrm{FIOH})$ and consists of seven items, with scores ranging from seven to 49 points. The result depicts the workers' concept of their own work ability: low capacity (7-27 points), moderate capacity (28-36), good capacity (37$43)$ or great capacity for work (44-49). ${ }^{1}$ For the analyses, it was dichotomized into "reduced capacity" (7-36 points) and "good/great capacity" (37-49 points).

Sociodemographic variables (gender, age, ethnicity/race, ${ }^{15}$ education, marital status), labor (function, labor sector, time in the function and in the sector, shift, weekly working hours, other job) and health features (health status compared to other people, health status compared to 12 months ago, sleep, smoking) were also analyzed.

To build the database, the data were included in Epi-Info ${ }^{\circledR}$, version 6.4 through independent double entry. After certifying the consistency of the data, the analysis was conducted in the software SASW Statistics ${ }^{\circledR}$ (Predictive Analytics Software, SPSS Inc.) 18.0 for Windows. Descriptive analyses and bivariate analyses were carried out to verify the association between exposure and the outcome of each of the covariates studied. The statistical significance of the associations was evaluated using the chi-square test $(\mathrm{p}<0.05)$.

Multivariate analysis was calculated by means of binary logistic regression. To select possible confounding variables (associated with both exposure and outcome), a confidence level of $75 \%(p \leq 0.25)$ was established. During the bivariate analyses, the following potential confounding factors were evidenced: gender, education, workload, other job, health status, current health status, sleep, smoking and age. Age was forced in the model, given that the greater the age, the lower the work ability may be. Logistic regression models were run for all variables that were removed from the models as the $p$ value was over $25 \%$. Multicollinearity evaluation was carried out on the model adopted by calculating the Variance Inflation Factor (VIF), where the minimum value is equal to 1.0 and values $>10.0$ may indicate collinearity problems. In this study, the VIF ranged from 1.020 to 1.596 , indicating absence of multicollinearity.

We used the Hosmer-Lemeshow Test to verify the adequacy of the regression models. In this test, the values range from zero $(0)$ to 1 , and the closer to 1 , the better the appropriateness of the model. ${ }^{16}$ The association measure used was the Odds Ratio (OR) and its respective confidence intervals $(95 \% \mathrm{CI})$.

\section{RESULTS}

Characterization of the population: the sociodemographic profile of the nursing workers appoints a predominance of females $(87.8 \%$; $n=437)$, aged $47-69$ years old $(32.7 \% ; n=163)$, mean of 41.3 years old ( \pm 8.9 years; minimum age of 24 and maximum of 69 years old), technical course in nursing $(36.1 \% ; n=180)$, married or living with a partner $(69.3 \% ; n=345)$. Concerning education, 129 (36.5\%) medical technicians / nursing assistants presented an undergraduate degree and $32(9.1 \%)$ possessed a graduate degree. The labor variables indicate the prevalence of medical technicians $(44.6 \%$; $=222)$, followed by nurses $(28.9 \% ; n=144)$ and nursing assistants (26.5\%; $\mathrm{n}=132)$, and professionals who worked at night $(40 \% ; n=199)$ and who had another job $(82.1 \% ; \mathrm{n}=409)$.

The prevalence of suspected MPD was $33.7 \%$. Table 1 contains the answers to the SRQ-20 items, distributed in four groups of symptoms. ${ }^{12}$

The average number of positive responses to the SRQ-20 was 4.77 ( \pm 3.96 ; minimum zero $(0)$ and maximum 17) and the median value was 4 . Table 1 describes the frequency of workers who chose the option "yes" to each question of the SRQ-20, permitting the identification of the prevalence and showing the concentration of workers in the group of somatic symptoms. 
Table 1 - Affirmative answers to the items of the Self-Reporting Questionnaire (SRQ-20) distributed in four groups of symptoms. Santa Maria-RS, $2012\left(n=430^{*}\right)$

\begin{tabular}{|c|c|c|c|}
\hline Group of symptoms & Self-Reporting Questionnaire-20 questions (SRQ-20) & $\mathbf{n}$ & $\%$ \\
\hline \multirow{4}{*}{ Depressive-anxious mood } & Do you feel nervous, tense or worried? & 292 & 67,9 \\
\hline & Do you startle easily? & 112 & 26,0 \\
\hline & Have you been sad lately? & 181 & 42,1 \\
\hline & Have you cried more than usual? & 86 & 20,0 \\
\hline \multirow{6}{*}{ Somatic symptoms } & Do you have frequent headaches? & 238 & 55,3 \\
\hline & Do you sleep badly? & 207 & 48,1 \\
\hline & Do you have unpleasant sensations in the stomach? & 202 & 46,9 \\
\hline & Do you have indigestion? & 145 & 33,7 \\
\hline & Do you have lack of appetite? & 34 & 7,9 \\
\hline & Do you have hand tremors? & 84 & 19,5 \\
\hline \multirow{6}{*}{ Vital energy decrease } & Do you get tired easily? & 175 & 40,7 \\
\hline & Do you have trouble making decisions? & 88 & 20,5 \\
\hline & Do you find it difficult to perform with satisfaction your daily activities? & 131 & 30,5 \\
\hline & Do you have difficulties at work (your job is painful, it causes you pain)? & 45 & 10,5 \\
\hline & Do you feel tired all the time? & 87 & 20,2 \\
\hline & Do you have difficulty thinking clearly? & 126 & 29,3 \\
\hline \multirow{4}{*}{ Depressive thoughts } & Are you unable to play a useful role in your life? & 39 & 9,1 \\
\hline & Have you lost interest in things? & 75 & 17,4 \\
\hline & Have you thought about ending your life? & 14 & 3,3 \\
\hline & Do you feel like a useless person? & 14 & 3,3 \\
\hline
\end{tabular}

* Of the 498 questionnaires, 68 containing blank responses were excluded (missing).

The distribution of nursing workers according to the WAI was classified as follows: $41.4 \%$ $(n=206)$, good work capacity; 37.6\% ( $n=187)$, moderate capacity; $15.3 \%(\mathrm{n}=76)$, great capacity; and $5.7 \%(n=29)$ low capacity. For the analysis, the classification of the WAI was dichotomized into good/great $(56.7 \%)$ and low/moderate $(43.3 \%)$ capacity. The latter was considered as reduction of work capacity.

Table 2 - Distribution of nursing workers of the University Hospital according to the responses on the Minor Psychiatric Disorders (MPD) Self-Reporting Questionnaire-20 and Work Ability Index (WAI), by sociodemographic characteristics. Santa Maria-RS 2012

\begin{tabular}{|c|c|c|c|c|c|c|c|c|c|c|}
\hline \multirow{3}{*}{ Sociodemographic variables } & \multicolumn{6}{|c|}{ MPD } & \multicolumn{4}{|c|}{ WAI } \\
\hline & \multirow{2}{*}{$\mathbf{n}$} & \multicolumn{2}{|c|}{ No } & \multicolumn{2}{|c|}{ Yes } & \multirow{2}{*}{$\mathrm{p}^{*}$} & \multirow[t]{2}{*}{$\mathbf{n}$} & \multicolumn{2}{|c|}{ Reduced Capacity } & \multirow[t]{2}{*}{$\mathrm{p}^{*}$} \\
\hline & & $\mathbf{n}$ & $\%$ & $\mathbf{n}$ & $\%$ & & & $\mathbf{n}$ & $\%$ & \\
\hline Gender & 428 & & & & & 0,011 & & & & 0.001 \\
\hline Female & & 248 & 64.4 & 137 & 35.6 & & 437 & 200 & 45.8 & \\
\hline Male & & 36 & 83.7 & 7 & 16.7 & & 59 & 14 & 23.7 & \\
\hline Age group & 414 & & & & & 0.589 & & & & 0.021 \\
\hline $24-36$ years old & & 94 & 67.1 & 46 & 32.9 & & 155 & 55 & 35.5 & \\
\hline $37-46$ years old & & 89 & 62.7 & 53 & 37.3 & & 162 & 69 & 42.6 & \\
\hline 47 to 69 years old & & 90 & 68.2 & 42 & 31.8 & & 163 & 83 & 50.9 & \\
\hline Education & 430 & & & & & 0.119 & & & & 0.108 \\
\hline High school & & 111 & 67.7 & 53 & 32.3 & & 192 & 84 & 43.7 & \\
\hline College & & 76 & 59.4 & 52 & 40.6 & & 143 & 71 & 49.7 & \\
\hline Graduate & & 98 & 71 & 40 & 29 & & 172 & 61 & 37.7 & \\
\hline Marital status & 426 & & & & & 0.502 & & & & 0.898 \\
\hline Married/with partner & & 195 & 65.7 & 102 & 34.3 & & 345 & 149 & 43.2 & \\
\hline Single/without partner & & 89 & 69 & 40 & 31 & & 148 & 63 & 42.6 & \\
\hline Ethnicity/race ${ }^{\dagger}$ & 425 & & & & & 0.916 & & & & 0.407 \\
\hline Black & & 6 & 60 & 4 & 40 & & 15 & 6 & 40.0 & \\
\hline Mulatto/Asian/Indigenous & & 30 & 66.7 & 15 & 33.3 & & 425 & 27 & 51.9 & \\
\hline White & & 245 & 66.2 & 125 & 33.8 & & 52 & 180 & 42.4 & \\
\hline
\end{tabular}

* Pearson's chi-square test; ${ }^{\dagger}$ Mulatto, indigenous and Asian. 
A significant difference was observed for suspected MPD $(35.6 \%, \mathrm{~N}=137)$ and reduction of work capacity $(45.8 \%$; $n=200)$ among female workers. Regarding the age group, it was identi- fied with statistical significance that, the greater the age, the higher the percentage of reduction of work capacity (Table 2).

Table 3 - Distribution of nursing workers of the University Hospital according to the responses on the Minor Psychiatric Disorders (MPD) Self-Reporting Questionnaire-20 and Work Ability Index (WAI), by labor characteristics. Santa Maria-RS 2012

\begin{tabular}{|c|c|c|c|c|c|c|c|c|c|c|}
\hline \multirow{3}{*}{ Labor variables } & \multicolumn{6}{|c|}{ MPD } & \multicolumn{4}{|c|}{ WAI } \\
\hline & \multirow{2}{*}{$\mathbf{n}$} & \multicolumn{2}{|c|}{ No } & \multicolumn{2}{|c|}{ Yes } & \multirow{2}{*}{$\mathrm{p}^{*}$} & \multirow{2}{*}{$\mathbf{n}$} & \multicolumn{2}{|c|}{ Reduced Capacity } & \multirow{2}{*}{$p^{*}$} \\
\hline & & $\mathbf{n}$ & $\%$ & $\mathbf{n}$ & $\%$ & & & $\mathbf{n}$ & $\%$ & \\
\hline Function & 430 & & & & & 0.276 & & & & 0.059 \\
\hline Nurse & & 85 & 70.2 & 36 & 29.8 & & 144 & 53 & 36.8 & \\
\hline $\begin{array}{l}\text { Medical technician/ } \\
\text { Nursing assistant }\end{array}$ & & 200 & 64.7 & 109 & 35.7 & & 354 & 163 & 46.0 & \\
\hline Weekly working hours & 430 & & & & & 0.082 & & & & 0.026 \\
\hline 30h per week & & 105 & 61.4 & 66 & 38.6 & & 187 & 93 & 49.7 & \\
\hline 36h per week & & 180 & 69.5 & 79 & 30.5 & & 311 & 123 & 39.5 & \\
\hline Work shift & 430 & & & & & 0.212 & & & & 0.645 \\
\hline Day & 430 & 122 & 69.7 & 53 & 30.3 & & 211 & 89 & 42.2 & \\
\hline Night & & 163 & 63.9 & 92 & 35.1 & & 287 & 127 & 44.3 & \\
\hline Work experience in the care sector & 418 & & & & & & & & & 0.606 \\
\hline Under 6 years & & 150 & 66.1 & 77 & 33.9 & 0.981 & 260 & 109 & 41.9 & \\
\hline$\geq 7$ years & & 126 & 66.0 & 65 & 34.0 & & 226 & 100 & 44.2 & \\
\hline Time on the job & 425 & & & & & 0.461 & & & & 0.106 \\
\hline Under 13 years & & 144 & 64.3 & 80 & 35.7 & & 255 & 101 & 39.6 & \\
\hline$\geq 14$ years & & 136 & 67.7 & 65 & 32.3 & & 237 & 111 & 46.8 & \\
\hline Another job & 430 & & & & & 0.007 & & & & 0.073 \\
\hline No & & 226 & 63.5 & 130 & 36.5 & & 409 & 185 & 45.2 & \\
\hline Yes & & 59 & 79.7 & 15 & 20.3 & & 89 & 31 & 34.8 & \\
\hline Hour load in other job & 70 & & & & & 0.868 & & & & 0.050 \\
\hline Up to $20 \mathrm{~h}$ & & 28 & 77.8 & 8 & 22.2 & & 39 & 17 & 43.6 & \\
\hline From $21-44 \mathrm{~h}$ & & 27 & 79.4 & 7 & 20.6 & & 43 & 10 & 23.3 & \\
\hline
\end{tabular}

* Pearson's chi-square test.

Considering the labor variables, not having another job was statistically significant for suspected MPD (36.5\%; $n=130)$. As regards the reduction of work capacity, the following were significant: a workload of 30 hours at the institution $(49.7 \%$; $n=93)$, having up to 20 hours of weekly work hours in another job (43.6\%; $\mathrm{n}=17)$, revealing a trend among medical technicians and nursing assistants $(\mathrm{p}=0.059)$.

Table 4 - Distribution of nursing staff of the University Hospital in accordance with the answers to the Minor Psychiatric Disorders (MPD) Self-Reporter Questionnaire-20 and Work Ability Index (WAI), by health characteristics. Santa Maria-RS 2012

\begin{tabular}{|c|c|c|c|c|c|c|c|c|c|c|}
\hline \multirow{3}{*}{ Health characteristics } & \multicolumn{6}{|c|}{ MPD } & \multicolumn{4}{|c|}{ WAI } \\
\hline & \multirow{2}{*}{ n } & \multicolumn{2}{|c|}{ No } & \multicolumn{2}{|c|}{ Yes } & \multirow{2}{*}{$\mathrm{p}^{*}$} & \multirow{2}{*}{$\mathbf{n}$} & \multicolumn{2}{|c|}{ Reduced Capacity } & \multirow{2}{*}{$\mathrm{p}^{*}$} \\
\hline & & $\mathrm{n}$ & $\%$ & $\mathbf{n}$ & $\%$ & & & $\mathrm{n}$ & $\%$ & \\
\hline Health condition compared to others & 430 & & & & & $<0.001$ & & & & $<0.001$ \\
\hline Very good & & 93 & 90 & 10 & 9.7 & & 142 & 26 & 18 & \\
\hline Good & & 166 & 68 & 80 & 33 & & 275 & 123 & 45 & \\
\hline Regular & & 25 & 33 & 50 & 67 & & 75 & 61 & 81 & \\
\hline Bad & & 1 & 17 & 5 & 83 & & 6 & 6 & 100 & \\
\hline Health status compared to 12 months ago & 429 & & & & & $<0.001$ & & & & $<0.001$ \\
\hline
\end{tabular}




\begin{tabular}{|c|c|c|c|c|c|c|c|c|c|c|}
\hline \multirow{3}{*}{ Health characteristics } & \multicolumn{6}{|c|}{ MPD } & \multicolumn{4}{|c|}{ WAI } \\
\hline & \multirow{2}{*}{$\mathbf{n}$} & \multicolumn{2}{|c|}{ No } & \multicolumn{2}{|c|}{ Yes } & \multirow{2}{*}{$\mathrm{p}^{*}$} & \multirow{2}{*}{$\mathbf{n}$} & \multicolumn{2}{|c|}{ Reduced Capacity } & \multirow{2}{*}{$\mathrm{p}^{*}$} \\
\hline & & $\mathbf{n}$ & $\%$ & $\mathbf{n}$ & $\%$ & & & $\mathbf{n}$ & $\%$ & \\
\hline Better & & 56 & 68 & 27 & 33 & & 102 & 47 & 42 & \\
\hline Equal & & 191 & 74 & 68 & 26 & & 307 & 109 & 36 & \\
\hline Worse & & 37 & 43 & 50 & 58 & & 88 & 60 & 68 & \\
\hline Sleep & 430 & & & & & $<0.001$ & & & & $<0.001$ \\
\hline Very dissatisfied & & 20 & 63 & 12 & 38 & & 44 & 16 & 36 & \\
\hline Dissatisfied & & 51 & 46 & 59 & 54 & & 112 & 63 & 65 & \\
\hline Neither satisfied nor dissatisfied & & 46 & 61 & 30 & 40 & & 80 & 42 & 53 & \\
\hline Satisfied & & 154 & 79 & 40 & 21 & & 235 & 79 & 34 & \\
\hline Very satisfied & & 14 & 78 & 4 & 22 & & 27 & 6 & 22 & \\
\hline Tobacco use & 428 & & & & & 0.1 & & & & 0.006 \\
\hline I have never smoked & & 210 & 68 & 99 & 32 & & 364 & 148 & 41 & \\
\hline I smoked, but stopped & & 56 & 71 & 23 & 29 & & 87 & 37 & 43 & \\
\hline Smoking & & 18 & 45 & 22 & 55 & & 44 & 29 & 66 & \\
\hline
\end{tabular}

* Pearson's chi-square test.

As for the health characteristics, there was a significant difference between the groups with respect to perceived health status as poor/worse (general and current) and being dissatisfied with one's sleep, for suspected MPD as well as for the reduction of work capacity. Smokers had a higher prevalence of low WAI.

The results of crude and adjusted analyses between MPD and reduction of work capacity are described in table 5 .

Table 5 - Crude and adjusted associations between Minor Psychiatric Disorder and reduction of work capacity. Santa Maria-RS 2012

\begin{tabular}{lcc}
\hline $\begin{array}{c}\text { Minor Psychiatric } \\
\text { Disorder }\end{array}$ & $\begin{array}{c}\text { WAI reduced } \\
\text { OR }(\mathbf{9 5 \%} \text { CI) }\end{array}$ & $\begin{array}{c}\text { Hosmer - } \\
\text { Lemeshow Test }\end{array}$ \\
\hline Crude Association $^{*}$ & $5.21(3.34-8.11)$ & - \\
Model 1 $^{\dagger}$ & $2.59(1.56-4.30)$ & 0.681 \\
Model 2 $^{\ddagger}$ & $\mathbf{2 . 7 0 ( 1 . 5 9 - 4 . 5 7 )}$ & $\mathbf{0 . 9 7 5}$ \\
Model 3 & $2.67(1.58-4.51)$ & 0.862 \\
Model 4 & $5.15(3.24-8.20)$ & 0.747 \\
\hline
\end{tabular}

*Crude association $=\mathrm{MPD} ;{ }^{\dagger} \mathrm{MPD}+$ gender + education + workload + other job + health status + current health status + sleep + smoking; ${ }^{\ddagger} \mathrm{MPD}+$ gender + education + workload + other job + health

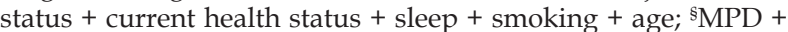
gender + workload + health status + current health status + sleep + smoking + age; $\mid$ MPD + gender + workload + age.

Table 5 shows that, according to the Hosmer-Lemeshow test, Model 2 is the one that best explains the association. Therefore, the adjusted analyses between MPDs and reduction of work capacity showed that, even after adjusting for confounding factors, the nursing workers with suspected MPD were twice as likely to have reduc- tion of work capacity (OR=2.70; 95\% CI=1.59-4.57) when compared to workers without suspicions.

\section{DISCUSSION}

The results of this study showed that nursing workers showing MPD are more likely $(\mathrm{OR}=2.70$; 95\% CI 1.59-4.57) to be classified with reduction of work capacity compared to those without suspicion, even after adjusting for possible confounding factors (gender, education, workload, other job, health status, current health status, sleep, smoking, age). Therefore, there was a positive association between MPD and reduction of work capacity in the workers surveyed.

Work is an activity that requires a direct relationship between physical and psychic aspects and may represent balance and satisfaction or cause tension and physical or psychological illness to the workers. ${ }^{3}$ With regard to nursing, these workers are subject to organizational stress and face an additional emotional demand inherent in their profession, as activities with biological, physical, chemical, ergonomic, mechanical, psychological and social risk. ${ }^{14}$ Thus, daily situations that cause stress, anxiety and suffering, such as pain experiences, feelings of helplessness and loss of patients, may lead workers to develop MPD.

In this study, it seems that such disorders may be negatively influencing the work ability in nursing. The positive association between MPD and reduction of work capacity appoints that its consequences are not only limited to physical and psychological damage caused to the employee, but also entail consequences throughout the service 
and can increase the number of work leaves. In this case, there would be even further overload on other workers, affecting the quality of care provided to the user.

The prevalence of suspected MPD (33.7\%) is higher compared to another study, ${ }^{4}$ which evaluated the association between psychological demand and job control and occurrence of minor psychiatric disorders among nursing workers. Thus, reflections are needed on the high percentage of workers classified with suspicion of MPD in this study, in order to achieve higher scores for work ability.

In this context, it is noteworthy that the results appoint that being a female worker, not having another job, considering one's health as poor, considering one's current health condition as worse compared to 12 months ago and being dissatisfied with sleep are conditions that can promote the development of MPD $(\mathrm{p}<0.05)$. Regarding the WAI, being female, being between 47 and 69 years old and having a weekly workload of 30 hours are conditions that can lead to reduction of work capacity $(\mathrm{p}<0.05)$. Some studies indicate that, with increased age, the work ability decreases and this decrease is more pronounced at ages higher than 45 years. ${ }^{17-18}$ These data can be explained by the morphological and physiological changes associated with aging.

Research results regarding suspected MPD in relation to gender, age, marital status, education and function, are not consensual. ${ }^{4,14}$ In this study, a higher prevalence of suspected MPD was identified among female workers aged between 37-46 years old, married, graduate and medical technicians or nursing assistants.

A study carried out with nursing professionals at the university hospital of the state of Rio Grande do Sul identified higher rates of MPD among male workers, aged 22-38, married or with a partner, non-graduate, and medical technicians or nursing assistants ${ }^{4}$. Another study, carried out with the nursing staff of the emergency unit of a general hospital in the city of Feira de Santana/Bahia, indicated the prevalence of suspected MPD in females older than 36 years old, unmarried, graduated, and in nurses, with twice the risk presented by medical technicians and nursing assistants. ${ }^{14}$

In this study, graduated and medical technicians or nursing assistants showed the highest suspected MPD. It is important to note that a considerable percentage of medical technicians and nursing assistants at the study hospital held undergraduate and graduate degrees but were still working as medical technicians or nursing assistants. It is known that the higher the education, the greater the possibility of choices in life, which influences future socioeconomic conditions and social inclusion in the occupational structure.

Perhaps this context of a higher qualification in relation to what is required by law for the position may have negative consequences on mental health though (higher percentage of MPD). Taking into account that these workers also showed a significant reduction of work capacity, this may entail consequences for physical health. This hypothesis is strengthened when identifying that $46 \%$ of the medical technicians and nursing assistants surveyed had reduction of work capacity, results higher than that found in another study with nursing assistants. ${ }^{19}$

The identification of a higher prevalence of suspected MPD among workers who did not have another job $(p=0.007)$ corroborates other studies., ${ }^{4,14}$ It is noteworthy that many workers of the research hospital who did not have another job worked extra shifts during their spare time, as a way to supplement their salary. Thus, they extended their workday and commited the time devoted to rest, leisure and family. By extending their workday, they end up intensifying the physical and psychological strain, resulting in factors that can lead to stress and illness, ${ }^{14}$ like mental disorders for example.

In addition, it brings back the discussion about the high percentage of workers who seek professional qualification through undergraduate and graduate programs, allocating their time off work to study. Nursing work by itself can be a source of burnout for workers, since workers are active in sectors that are considered stressful because of the workload, as particularities of the tasks. ${ }^{14}$ Thus, it is believed that the nursing work, combined with the study, which also deserves time, can cause physical and mental burnout in the workers.

Although not statistically significant $(p=0.073)$, the study found that $45.2 \%$ of workers who did not have another job were classified with reduction of work capacity, which is perhaps indicating that the increase in work hours due to overtime may influence work ability.

The results presented outline that the SRQ20 questions had a higher prevalence of positive responses, which were related to the group of somatic symptoms and should be carefully 
analyzed, as they appointed symptoms that can interfere negatively in the work ability, such as headaches, sleeping poorly, unpleasant sensations in the stomach and indigestion. In this context, it is necessary to seek an environment with better work conditions, as well as measures to promote health, prevention of diseases and listening along with the nursing staff, and an available and active health service for the workers.

In addition, it is important to develop and implement strategies aimed at reducing risks and promoting health and safety at work, ${ }^{19}$ thus contributing to the maintenance of work ability. Improvements in the work conditions of the nursing staff influence not only the workers' health, but also the entire service, in view of a smaller number of absences, which affect the care offered to patients.

Despite the limitations of cross-sectional designs in establishing cause and effect relationships, as well as the bias resulting from the prevalence of the healthy worker effect, it is believed that these problems are minimized, because minor psychiatric disorders are considered as a chronic outcome of high prevalence, with comparisons being made among the nursing staff.

\section{CONCLUSIONS}

The results of this study confirm the research hypothesis, since they indicate that the nursing workers with suspected MPD were twice as likely to have reduction of work capacity compared to workers without suspected MPD, even after adjusting for possible confounding factors.

The high prevalence of both MPD (33.7\%) and reduction of work capacity $(43.3 \%)$ denotes a health problem that needs tot be continually investigated because the demands and pressures of a profession that deals with suffering and illness daily can enhance the emergence of these diseases. Thus, it is important to look at these workers carefully, searching for measures of health promotion, illness prevention, listening to the nursing workers. In addition, the institution needs to provide for a health service for active workers.

The study contributes to the evaluation of mental health related to work ability of nursing workers, identifying occurrence patterns and associated factors. The relevance of the findings on the sociodemographic, employment and health characteristics suggests that the reduction of mental and physical health problems in nursing workers depends on the workers and managers in favor of improvements in work conditions.

The instruments (WAI and SRQ-20) used in this study are easy to apply. In this sense, followup studies with the workers of this study are suggested. Wide-ranging epidemiological studies are useful to evaluate work and health conditions at hospitals. These may suggest causal evidence and support the design of policies focused on health workers, including interventions for the promotion of mental health, risk prevention and control of work capacity hazards.

\section{ACKNOWLEDGMENTS}

To the Universidade Federal de Santa Maria and the state of Rio Grande do Sul Research Support Foundation (FAPERS) for its financial support (Scientific Initiation Scholarship - FIPE enxoval/ UFSM, Fipe Jr./UFSM and PIBIC/CNPq, Financial support ARD/FAPERGS) and support in the research development.

\section{REFERENCES}

1. Tuomi K, Ilmarinen J, Jahkola A, Katajarinne L, Tulkki A. Índice de capacidade para o trabalho. São Carlos (SP): Universidade Federal de São Carlos; 2005.

2. Kirchhof ALC, Lacerda MR, Sarquis LMM, Magnago TSBS, Gomes IM. Compreendendo cargas de trabalho na pesquisa em saúde ocupacional na enfermagem. Colombia Medica. 2011 Abr-Jun; 42(Supl 1):113-9.

3. Dejours C. A carga psíquica do trabalho. In: Betiol MIS, Coordenador. Psicodinâmica do trabalho: contribuições da Escola dejouriana à análise da relação prazer, sofrimento e trabalho. São Paulo (SP): Atlas; 2007. p. 21-32.

4. Kirchhof ALC, Magnago TSBS, Camponogara S, Griep RH, Tavares JP, Prestes FC et al. Condições de trabalho e características sociodemográficas relacionadas à presença de distúrbios psíquicos menores em trabalhadores de enfermagem. Texto Contexto Enferm. 2009 Abr-Jun; 18(2):215-23.

5. Cerchiari EAN, Caetano D, Faccenda O. Prevalência de transtornos mentais menores em estudantes universitários. Estud Psicol. 2005 Set-Dez; 10(3):413-20.

6. Hilleshein EF, Souza LM, Lautert L, Paz AA, Catalan VM, Teixeira MG, et al. Capacidade para o trabalho de enfermeiros de um hospital universitário. Rev Gaúcha Enferm. 2011 Set; 32(3):509-15.

7. Negeliskii C, Lautert L. Occupational stress and work capacity of nurses of a hospital group. Rev Latino-Am Enfermagem. 2011 Mai-Jun; 19(3):606-13. 
8. Hilleshein EF, Lautert L. Work capacity, sociodemographic and work characteristics of nurses at a university hospital. Rev Latino-Am. Enfermagem. 2012 Mai-Jun; 20(3):520-7.

9. Derycke H, Clays E, Vlerick P, D'Hoore W, Hasselhorn HM, Braeckman L. Perceived work ability and turnover intentions: a prospective study among Belgian healthcare workers. J Adv Nurs. 2012 Jul; 68(7):1556-66.

10. Nussbaumer L, Dapper V, Kalil F. Agravos relacionados ao trabalho notificados no Sistema de Informações em Saúde do Trabalhador no Rio Grande do Sul, 2009. Bol Epidemiol. 2010; 12(1):5-8.

11. Mari JJ, Williams P. A validity study of a psychiatric screening questionnaire (SQR-20) in primary care in the city of São Paulo. Br J Psychiatry. 1986 Jan; 148:23-6.

12. Santos KOB, Araújo TM, Oliveira NF. Estrutura fatorial e consistência interna do Self-Reporting Questionnaire (SRQ-20) em população urbana. Cad Saúde Pública. 2009 Jan; 25(1): 214-22.

13. World Health Organization. A user's guide to the self reporting questionnarie (SRQ): Division of Mental Health. Geneva (CH): World Health Organization; 1994.
14. Pinho PS, Araújo TM. Trabalho de enfermagem em uma unidade de emergência hospitalar e transtornos mentais. Rev Enferm UERJ. 2007 Jul-Set; 15(3):32936.

15. Instituto Brasileiro de Geografia e Estatística. Características étnico-raciais da população: um estudo das categorias de classificação de cor ou raça [internet]. Brasília (DF) IBGE; 2008 [acesso 2013 Jul 23]. Disponível em: http:/ / www.ibge.gov. $\mathrm{br} /$ home/estatistica/populacao/caracteristicas_ raciais/PCERP2008.pdf

16. Hosmer DW, Lemeshow S. Applied logistic regression. New York (EUA): Wiley; 2000.

17. Goedhard R, Goedhard E, Goedhard W. Aspects of stress, shift work and work ability in relation to age. In: Proceedings of the 4th Symposium on Work Ability, 2011 Jun 144-9; Tampere, Finland. Tampere (FI): Tampere University Press; 2011.

18. Berg T, Elders L, Zwart B, Burdorf A. The effects of work-related and individual factors on the Work Ability Index: a systematic review. Occup Environ Med. 2009 Nov; 66(4): 211-20.

19. Monteiro MS, Alexandre NMC, Milni D, Fujimura F. Work capacity evaluation among nursing aides. Rev Esc Enferm USP. 2011 Out; 45(5):1177-82. 